\section{Dr. Bahadir Ozcan' \\ Dr. Hakki Kontas ${ }^{2}$ \\ Dr. Ali Unisen ${ }^{3}$}

Faculty of Education, Adiyaman University, Adiyaman, Turkey
Original scientific paper

UDC: 371.26

DOI: $10.5937 /$ IstrPed2101085O

\title{
SOURCES OF MATHEMATICS SELF-EFFICACY OF GIFTED AND NON-GIFTED STUDENTS IN HIGH SCHOOL
}

\begin{abstract}
Sources of mathematics self-efficacy (SMS), which foster the development of self-efficacy belief, can develop differently in students with different cognitive characteristics. The objective of this study was to compare SMS of gifted and nongifted students after controlling for mathematics achievement. Participants of the study consisted of 106 gifted and 118 non-gifted students in high schools. The study was a causal-comparative design. The data was collected through the Sources of Mathematics Self-Efficacy Scale, and students' self-reported previous fall mathematical grades. The results of the study revealed that after controlling for mathematics grades, while SMS of gifted children sharply decreased, SMS in the nongifted group slightly increased. In addition, only vicarious experience dimensions of SMS were significantly different between gifted and non-gifted children. In conclusion, being gifted or non-gifted has an impact on the vicarious experience dimensions of SMS after controlling for mathematics achievement. Mathematics grade positively affects SMS in the gifted group and negatively affects the non-gifted group. Teachers are suggested to use achievement as a reinforcer for gifted students but not for non-gifted students.
\end{abstract}

Keywords: Giftedness, mathematic achievement, self-efficacy, vicarious experience.

\section{Introduction}

Self-efficacy is a construct affecting one's accomplishment, learning, behavior, feeling, and cognition in life. It forms one of the central components of Bandura's social cognitive theory. Self-efficacy is a belief constructed by individuals as to whether they can successfully complete a task by interpreting their antecedent experience, vicarious experience, social persuasions, and emotional arousal jointly (Bandura, 1997; Lin et al., 2018). Their judgments of confidence in performing a given task or succeeding in an academic activity predict their subsequent capability to perform similar tasks or thrive in the same situations (Pajares \& Graham, 1999).

According to Pajares (1996), self-efficacy is the effort put forth to accomplish a task and persistence in the face of problems. Lloyd et al. (2005) argued that achievement gains are

\footnotetext{
${ }^{1}$ bhdozcan@yahoo.com

2hkontas@adiyaman.edu.tr

3 aunisen@adiyaman.edu.tr
} 
insufficient unless the self-efficacy beliefs have changed correspondingly, and Pajares (1996) emphasizes the causality of beliefs suggesting an underestimation capability rather than a lack of skill, being responsible for students' avoidance of certain courses and careers. These beliefs refer to future functioning and are assessed before students perform relevant activities. These previous properties determine that self-efficacy judgments play a causal role in academic motivation as well (Zimmerman, 2000). Students who believe they can successfully accomplish a task will continue to work on the activity despite its challenge (Stevens et al., 2004). Students with a high level of self-efficacy expend greater effort, attention, and perseverance when solving problems (Pajares \& Kranzler, 1995).

\subsection{Sources of Self-Efficacy}

Self-efficacy beliefs develop through the interpretation of information from four primary sources; mastery experience, vicarious experience, verbal persuasions, and physiological and affective state (Bandura, 1997). The contribution of each source to the development of selfefficacy may vary depending on the domain and how the students process the related information (Usher \& Pajares, 2009).

The first source of self-efficacy -mastery experience- refers to the beliefs of competence resulting from one's previous experiences in a related task. Past performance shapes a person's present self-efficacy beliefs by relying on past success and mastery of tasks (Lin et al., 2018). Favorably interpreted previous performances result in the development of positive beliefs to engage in similar subsequent tasks. The more challenging a success is, the more it raises an individual's sense of self-efficacy (Britner \& Pajares, 2006). Personal experiences have permanent impacts on self-efficacy and construct the most prominent source of a students' self-efficacy as they provide authentic evidence that they can succeed at the task (Bong \& Skaalvik, 2003; Warwick, 2008).

Vicarious experience, which is the second source of self-efficacy, is the observation of someone's performance on a particular task (Usher \& Pajares, 2006). Children compare themselves to individuals such as classmates, peers, and adults as they judge their capacity and use this information to understand whether they can succeed at the same or similar tasks (Britner \& Pajares, 2006). Vicarious experience has lower impacts on self-efficacy than mastery experience (Bandura, 1997). When individuals perform better than their peers whom they observe, their self-efficacy expectancy increases but lowers when they are surpassed (Loo \& Choy, 2013).

The third source of self-efficacy-social persuasion-refers to encouragement, discouragement feedback, appraisals, and judgments from significant people, such as parents, teachers, and friends (Bandura, 1997). Favorable encouragement, feedback, judgments, and appraisals may enhance students' self-efficacy while unfavorable ones lower it (Bandura, 1997). However, social persuasions alone do not produce a positive sense of self-efficacy; rather, they do so in accord with other sources of self-efficacy (Bandura, 1997; Britner \& Pajares, 2006). Zeldin and Pajares (2000) found verbal persuasion and vicarious experiences to be critical sources of women's self-efficacy beliefs.

The last source of self-efficacy is physiological state, which refers to emotions or physical sensations such as stress, anxiety, exhaustion, anger, and calmness while one is carrying out a given task (Bandura, 1997; Usher \& Pajares, 2006). Bandura (1997) stated that the self-efficacy 
of students is at an optimum level when the physiological cues are neither too high nor too low. Physical responses in stressful situations play a vital role in self-efficacy; for instance, high emotional arousal may lower performance, as it may cause dysfunction (Brookby, 2004). People who can control their emotional arousal sustain their self-efficacy in stressful situations (Bandura, 1997).

These four sources interact dynamically to affect self-efficacy judgments and have been highly interrelated (Lent et al., 1996). Perceptions of ability, the amount of effort endeavored, the difficulty of the task, the amount and type of help received from others, similarity to models, the credibility of the persuader, and patterns of successes and failures are all taken into account in process of appraising self-efficacy beliefs (Bandura, 1997).

\subsection{Self-Efficacy and Mathematics Achievement}

Self-efficacy in a subject determines whether the individual will continue to study it and pursue a related career (Betz \& Hackett, 1983; Hacket \& Betz, 1981; Rodrigez, 2003; Vogel \& Human-Vogel, 2016). It is also sensitive to the academic domain (Butz \& Usher, 2015; Zeldin et al., 2008). Students' self-efficacy beliefs influence academic achievement, motivation, and level of engagement (Britner \& Pajares, 2006; Butz \& Usher, 2015; Klassen \& Usher, 2010; Pajares \& Kranzler, 1995; Schweinle \& Mims, 2009), performance in terms of general mental ability (Pajares \& Kranzler, 1995), development of academic skills (Klassen \& Usher, 2010; Tracy, 2013), interest in and selection of a course, persistence in a task, and self-regulatory strategies (Pajares, 1996; Usher \& Weidner, 2018). Moreover, self-efficacy is the most consistent predictor of academic achievement (Klassen \& Usher, 2010; Tracy, 2013). Selfefficacy, besides its various effects mentioned above, is related to mathematics achievement as well.

Each member of society must know how to use the basics of mathematics in their daily lives. Every student must learn mathematical thinking and think mathematically to learn (Kilpatrick et al., 2001). Mathematics self-efficacy is a situational or problem-specific assessment of students' confidence in their ability to successfully perform or accomplish a particular mathematics task or problem (Hackett \& Betz, 1989). Mathematics self-efficacy has a valued place across the world, as mathematics is a filter for students in pursuit of scientific and technical careers at a higher education level (Falco, 2019; Pajares \& Graham, 1999; Sukthanker, 1999). O'brien et al. (1999) reported a low number of minorities in science and engineering due to deficits in self-efficacy or self-perceived skills in mathematics. Mathematics achievement is related not only to self-efficacy beliefs (Masitoh \& Fitriyani, 2018; Watson, 2015; Zimmerman et al., 2011) but also to SMS beliefs (Arslan, 2013; Choy, 2013; Kesan \& Kaya, 2018; Ozcan \& Kontas, 2020; Ozcan \& Kontas, 2017; Ozcan \& Kultur, 2019). On the contrary, recent studies have examined the possibility of the interplay of self-efficacy and academic achievement. It was pointed out that the positive effect of past academic achievement on self-efficacy is higher than the effect of self-efficacy on academic achievement (Hwang et al., 2016; Talsmaet al., 2018).

\subsection{Self-Efficacy in Gifted Children}

One of the basic features of gifted children is that they have the potential to perform significantly higher than their non-gifted peers of the same chronological age (Gagne, 2003; Harrison, 2004; Sternberg \& Kaufman, 2018; Tannenbaum, 1997). Gifted children are different 
from non-gifted children in that they are highly motivated (Malpass et al., 1999); have high confidence in themselves, superior analytic abilities, and high memory capacity; enjoy learning; extrapolate knowledge to new situations; use high-level thinking skills; and are keen observers, multipotential (Kuo et al., 2010; Risemberg \& Zimmerman, 2010; Tunnicliffe, 2010; Wallace, 2000), perfectionists (Neumeister, 2004; Madigan, 2019; Rimm, 2003; Roberts \& Lovett, 1994), autonomous learners (Gottfried et al., 1994; Betts, 1986; Betts \& Neihart, 1988; Vallerand et al., 1994; Little, 1995), and more competent (Malpass et al., 1999). Unchallenging tasks do not satisfy their need for achievement (Lens \& Rand, 2000). Gifted children seem to be more accurate in estimating their self-efficacy (Pajares \& Graham, 1999). These characteristics are general traits of gifted children, and they may directly or indirectly affect the development of their self-efficacy beliefs, as many of these characteristics have an impact on the interpretation of the information they obtain from their experiences. Different characteristics of gifted students may also make a difference in SMS experiences that enables them to develop mathematics self-efficacy beliefs. In this sense, knowing the differences of SMS between gifted and non-gifted students would guide in planning the learning and teaching processes for gifted and non-gifted children. This study proposed that SMS would differ according to a child's being either gifted or non-gifted.

\subsection{The Present Study}

Gifted children have different cognitive and emotional characteristics than their non-gifted peers. SMS are among the fields in which these cognitive and emotional characteristics can be traced. One of the significances of this study is that it examines SMS in the gifted group. In this study, high school students' SMS were examined in terms of their being gifted or nongifted. In addition, after controlling for mathematics achievement, the study proposed that SMS in gifted and non-gifted students would differ. The present study aimed to compare SMS, the mastery experience, the vicarious experience, social persuasions, and the physiological state of gifted high school students and non-gifted peers after controlling for mathematics achievement.

\section{Method}

\subsection{Participants}

In this study, the causal-comparative design was used to compare SMS in terms of being gifted or non-gifted. Causal-comparative research is applied to investigate the effect of an independent variable on a dependent variable by comparing two or more groups of participants (Fraenkel et al., 2012). Participants of the study were a total of 224 high school students. Of the participants, $47.3 \%(n=106)$ were gifted students and $52.7 \%(118)$ were nongifted students. As for gender, $53.1 \%(n=119)$ of students were female and $46.9 \%(n=105)$ were male. The participants' ages ranged from 14 years to 18 years. The gifted students in the sample had been identified as gifted through achievement and IQ tests by the Ministry of National Education (MoNE). Gifted students participate in an enriched support program at a Science and Art Centre. The participants were located in four cities of the Mediterranean and the Southeast region of Turkey. Gifted students also received the regular nationwide education program deployed at their schools. Non-gifted participants were from a high school recruiting students from among mid-level successful ones on the University Entrance Exams and who applied for the transition from high school to university education. The participants were informed that participation in the research was voluntary, they could drop out at any 
stage, and their demographic and previous academic data would be used exclusively for the related research.

\subsection{Instrument}

The Sources of Mathematics Self-Efficacy Scale was used to measure SMS. Mathematics achievement was determined by asking the students for their previous semester mathematics course grade. Before the instrument's application, teachers were informed about the tool's application process and ethical obligations. After these processes, the teachers applied the instruments in the lesson.

\subsubsection{Sources of Mathematics Self-Efficacy Scale}

The scale was developed by Usher and Pajares (2009) to measure four SMS beliefs of middle school students. There were 24 items on a 7-point Likert-type scale. The scale items were ranked from 1 "completely disagree" to 7 "completely agree." Seven negative were items scored reversely on the scale. The scale had four subscales (mastery experience, vicarious experience, social persuasions, and physiological state), each of which had six items, Kontas and Ozcan (2017) adapted the scale into Turkish culture in middle schools. Moreover, Ozcan and Kontas (2020) conducted validity and reliability studies of the scale for high school students.

Results of Confirmatory Factor Analysis (CFA) on high school students were $\chi_{2} / \mathrm{sd}=2.41$, RMSEA $=.07, \mathrm{CFI}=.98, \mathrm{NNFI}=.98$, and SRMR $=.05$. Cronbach's Alpha coefficient was calculated as $\alpha=.87$ for mastery experience, $\alpha=.85$ for vicarious experience, $\alpha=.95$ for social persuasions, and $a=.94$ for physiological state. All these values suggest high internal consistency (Ozcan \& Kontas, 2020). The findings proved that the scale is valid and reliable for high school students.

\subsubsection{Mathematics achievement}

In this study, mathematics achievement was the students' previous semester mathematics course mean scores taken from exams. There are two written exams and two performance points for each semester. One performance point consists of the individual or group work done under the supervision of the lesson teacher. The other performance point is given according to the student's course preparation, attendance, active participation, and exemplary behavior. Written exams and performance studies are evaluated out of 100 points. At the end of the semester, to be successful in a mathematics course, the student must have a mean score of at least 50 out of 100 (MoNE, 2017).

\subsection{Data Analysis}

To limit Type I error, we conducted a one-way multivariate analysis of covariance (MANCOVA) through Statistical Package for the Social Sciences (SPSS 21). The dependent variables were the sources of mathematics self-efficacy: mastery experience, vicarious experience, social persuasions, and physiological state. The Independent variable was being gifted or non-gifted, and the covariate variable was mathematics grade. 


\section{Findings}

Before investigation of the treatment effects with MANCOVA, various assumptions were tested. At first, the assumption of normal distribution was successfully verified by skewness and kurtosis statistics in terms of the dependent and covariate variables (skewness values ranged from .352 to 1.104 and kurtosis from .117 to 1.191). Second, the homogeneity of variance was satisfied among the covariance matrices by a nonsignificant Box's $M$ test, $F(10,224160)=$ $17.04, p=.081$. Third, in a covariate analysis, covariates must be correlated with the dependent variables (Hair et al., 1998). A correlation matrix suggested that the covariate variable, math grades, was correlated with mastery experience, vicarious experience, social persuasions, and physiological state. Fourth, before using MANCOVA, it is important to identify any outliers that affect the level of type I error and distort the results (Hair et al., 1998). There were three multivariate outliers in the data, as assessed by Mahalanobis distance ( $p>.001)$. Thus, the sample size was reduced from 224 to 221 participants. Fifth, the homogeneity of variance was assessed through Levene's test. Mastery experience, vicarious experience, and social persuasions were not significant, and they have been met homogeneity of variances' assumption. The physiological state variable violated the assumption of homogeneity of variances. However, because the sample sizes of gifted and non-gifted children are almost equal (105 and 116), this is not a big problem. It is also vital to have homogeneity of variances, especially if sample sizes differ across levels of the variables (Leech et al., 2005).

A one-way MANCOVA was performed to determine the effect of being gifted or non-gifted on sources of math self-efficacy: mastery experience, vicarious experience, social persuasions, and physiological state after controlling for math grade. Table 1 presents the descriptive statistics (unadjusted means and standard deviations, and adjusted means and standardized errors) for the four sources of math self-efficacy, while Table 2 presents the MANCOVA results.

Means and adjusted means of mastery experience, vicarious experience, social persuasions, and physiological state were not similar. All sources of math self-efficacy showed a general trend to increase in the non-gifted group, but all sources of math self-efficacy decreased in the gifted group (see Table 1).

Table 1. Adjusted and unadjusted gifted/non-gifted means and variability for SMS using math grades as a covariate

\begin{tabular}{lllllll}
\hline Sources of self-efficacy & & \multicolumn{3}{c}{ Unadjusted } & \multicolumn{2}{c}{ Adjusted } \\
\cline { 3 - 6 } & & $\mathrm{N}$ & $\mathrm{M}$ & $\mathrm{SD}$ & $\mathrm{M}$ & $\mathrm{SE}$ \\
\hline Mastery experience & Gifted & 105 & 31.48 & 7.82 & 25.45 & .76 \\
& Non-gifted & 116 & 22.53 & 8.25 & 25.24 & .71 \\
Vicarious experience & Gifted & 105 & 27.85 & 9.28 & 22.61 & .98 \\
& Non-gifted & 116 & 27.96 & 8.91 & 29.13 & .92 \\
Social persuasions & Gifted & 105 & 29.95 & 8.94 & 22.63 & .92 \\
& Non-gifted & 116 & 19.45 & 10.46 & 22.73 & .86 \\
Physiological state & Gifted & 105 & 33.17 & 9.34 & 26.34 & 1.12 \\
& Non-gifted & 116 & 27.71 & 11.88 & 29.82 & 1.05 \\
\hline
\end{tabular}

The one-way MANCOVA showed a significant difference between the gifted and non-gifted groups in terms of the SMS: mastery experience, vicarious experience, social persuasions, and physiological state, after controlling for math grade $(F(4,215)=7.048, p<.001$, Wilks' $\Lambda=.884$, partial $\eta 2=.116)$. Follow-up univariate one-way ANCOVAs indicated that there were significant differences in adjusted means for vicarious experience $(F(1,218)=17.527, p<.001$, partial $\eta 2=$ 
$.074)$, but not for the mastery experience $(F(1,218)=.064, p=.801$, partial $\eta 2=.000)$, social persuasions $(F(1,218)=.000, p=.994$, partial $\eta 2=.000)$, and physiological state $(F(1,218)=$ $3.658, p=.058$, partial $\eta 2=.017)$. These findings meant that there was a significant adjusted mean difference of vicarious experience between gifted and non-gifted groups. However, there were no significant adjusted mean differences of mastery experience, social persuasions, and physiological state.

Table 2. Multivariate analysis of covariance (MANCOVA): Effects of being gifted or non-gifted on SMS

\begin{tabular}{|c|c|c|c|c|c|c|}
\hline & & $d f$ & MS & $F$ & $p$ & partial $\eta^{2}$ \\
\hline \multirow{3}{*}{ Mastery experience } & Fixed factors & & & & & \\
\hline & $\begin{array}{l}\text { Gifted/non-gifted } \\
\text { Covariate }\end{array}$ & 1 & 2.67 & .06 & .801 & .00 \\
\hline & $\begin{array}{l}\text { Math grades } \\
\text { Fixed factors }\end{array}$ & 1 & 5029.11 & 119.89 & .000 & .36 \\
\hline \multirow[t]{2}{*}{ Vicarious experience } & $\begin{array}{l}\text { Gifted/non-gifted } \\
\text { Covariate }\end{array}$ & 1 & 1240.56 & 17.53 & .000 & .07 \\
\hline & $\begin{array}{l}\text { Math grades } \\
\text { Fixed factors }\end{array}$ & 1 & 2656.79 & 37.54 & .000 & .15 \\
\hline \multirow[t]{2}{*}{ Social persuasions } & $\begin{array}{l}\text { Gifted/non-gifted } \\
\text { Covariate }\end{array}$ & 1 & .00 & .00 & .964 & .00 \\
\hline & $\begin{array}{l}\text { Math grades } \\
\text { Fixed factors }\end{array}$ & 1 & 7370.85 & 118.79 & .000 & .35 \\
\hline \multirow[t]{2}{*}{ Physiological state } & $\begin{array}{l}\text { Gifted/non-gifted } \\
\text { Covariate }\end{array}$ & 1 & 337.59 & 3.66 & .057 & .02 \\
\hline & Math grades & 1 & 5181.71 & 56.14 & .000 & .21 \\
\hline
\end{tabular}

Note. $\mathrm{N}=221$

The covariate variable, math grade, had a significant effect on the sources of math selfefficacy: mastery experience, vicarious experience, social persuasions, and physiological state. Multivariate tests indicated that math grade was significantly related to the sources of math self-efficacy $(F(4,215)=34.387$, Wilks' $\Lambda=.610, p<.001$, partial $\eta 2=.390)$. Follow-up analyses of ANOVA tests indicated that math grade was significantly related to mastery experience $(F(1,218)=119.893, p<.001$, partial $\eta 2=.355)$, vicarious experience $(F(1,218)=37.536, p<.001$, partial $\eta 2=.147)$, social persuasions $(F(1,218)=118.792, p<.001$, partial $\eta 2=.353)$, and physiological state $(F(1,218)=56.137, p<.001$, partial $\eta 2=.205)$.

Pairwise comparisons with a Bonferroni-adjusted p-value were made for the sources of math self-efficacy. The non-gifted group had a significantly higher adjusted mean vicarious experience as compared to the gifted group, an adjusted mean difference of $6.404(95 \% \mathrm{Cl}$, 3.389 to 9.419$), p<.001$. However, the other three sources of math self-efficacy-mastery experience, social persuasions, and physiological state-were not statistically significant (see Table 2). The results exhibited that the participants in the non-gifted group reported a significantly higher mean than those in the gifted group in terms of vicarious experience.

\section{Discussion and Conclusion}

The current study aimed to determine the effect of being gifted or non-gifted on sources of mathematics self-efficacy -mastery experience, vicarious experience, social persuasions, and physiological state- after controlling for mathematics grade. The findings showed that means and adjusted means of mastery experience, vicarious experience, social persuasions, and physiological state were not similar in both gifted and non-gifted students. After controlling 
for the mathematics grade, all SMS showed a general slight increase in the non-gifted group. In contrast, all sources of math self-efficacy sharply decreased in the gifted group (see Table 1). When unadjusted mean scores of SMS of the gifted and non-gifted groups were compared, mastery experience, social persuasion, and psychological state scores in gifted students were higher. In contrast, vicarious experience scores seemed close to each other. When adjusted means were compared between gifted and non-gifted groups, vicarious experience and the physiological state of non-gifted students were higher than those of the gifted group. In contrast, the other two SMS -mastery experience and social persuasions- were close to each other.

Controlling mathematics achievement caused a sharp decrease in the adjusted mean of gifted students and a slight increase in the adjusted mean of the non-gifted group. A decrease in SMS can be explained through perfectionism, one characteristic of giftedness. Perfectionism encourages gifted students to strive for the highest possible mathematics achievement; after controlling for mathematics achievement, this motive disappeared. Studies on the relationships between perfectionism and performance supported this finding (Madigan, 2019; Neumeister, 2004). The decreases in the adjusted means of the gifted group can also be attributed to their being autonomous learners (Gottfried et al., 1994; Betts, 1986; Betts \& Neihart, 1988; Little, 1995; Vallerand et al., 1994). For that reason, they need rather less SMS. When adjusted mean scores were compared between gifted and non-gifted groups, vicarious experience and physiological state were higher in the non-gifted group. These differences can also be attributed to the autonomous learning characteristic of giftedness, as autonomous learners need rather less experience (Betts, 1986).

Another result of the study was that SMS significantly differed in terms of being gifted or nongifted after controlling for mathematics grade. ANCOVA results indicated significant differences in the vicarious experience dimension of SMS between gifted and non-gifted groups. However, there were no significant differences in mastery experience, social persuasions, and physiological state. The fact that gifted children have a lower level of vicarious experience as compared to non-gifted children can be explained by the precocity trait of giftedness. They needed less vicarious experience for the development of self-efficacy. Gifted students are always a step ahead of their peers in cognitive and emotional development (Gagne, 2003; Harrison, 2004; Sternberg \& Kaufman, 2018; Tannenbaum, 1997). Moreover, as the gifted students share the same learning environments with their non-gifted peers, they have less of a chance to learn through observation.

The results related to the covariate variable, mathematics achievement, showed that mathematics achievement had a significant effect on the four SMS: mastery experience, vicarious experience, social persuasions, and physiological state. Some studies showed that self-efficacy affected mathematics achievement (Bonne \& Johnston, 2016; Grigget al., 2018; Masitoh \& Fitriyani, 2018; Schober et al., 2018; Tossavainen et al., 2019; Watson, 2015; Zimmerman et al., 2011) and that SMS affected academic achievement (Arslan, 2013; Choy, 2013; Kesan \& Kaya, 2018; Ozcan \& Kontas, 2017; Ozcan \& Kontas, 2020). This study indicated that mathematics achievement influenced SMS, and it is consistent with studies showing that academic achievement affects self-efficacy (Hwang et al., 2016; Talsma et al., 2018).

In conclusion, being gifted or non-gifted affects the vicarious experience dimension of SMS. Mathematics achievement has a positive motivational effect on SMS of non-gifted students and negative effects on gifted groups. Academic achievement is a powerful predictor for SMS. 
Teachers should use mathematics grades as a positive reinforcer to increase SMS in gifted students. In contrast, mathematics grade is a negative reinforcer for non-gifted groups, and it should be avoided in this group. When one is planning activities to increase self-efficacy beliefs, taking the effects of self-efficacy on achievement, complying activities should be designed. Achievement experiences affected the students' sources of self-efficacy. Then, students should be provided with more chances to live achievement in the school context to develop their self-efficacy beliefs.

This research was conducted to compare gifted and mid-achiever non-gifted students. It is advised that researchers repeat the study with low- and high-achiever non-gifted students. The socio-economic levels of the participants were not taken as a variable in the study; thus, ensuing studies should include students' socio-economic levels. More research is required to clarify the interplay between achievement, self-efficacy, and sources of self-efficacy.

\section{Acknowledgements}

An earlier version of this study was presented at the VIIth International Eurasian Educational Research Congress, Ankara, Turkey, 19-22 June 2019.

\section{References}

Arslan, A. (2013). Investigation of the relationship between sources of self-efficacy beliefs of secondary school students and some variables. Educational Sciences: Theory and Practice, 13(4), 1983-1993. http://doi.org/10.12738/estp.2013.4.1753

Bandura, A. (1997). Self-efficacy: The exercise of control. W. H. Freeman \& Company.

Betts, G. T. (1986). The autonomous learner model: for the gifted and talented. LPS Publishing.

Betts, G. T., \& Neihart, M. (1988). Profiles of the gifted and talented.Gifted child quarterly, 32(2), 248-253.

Betz, N. E., \& Hackett, G. (1983). The relationship of mathematics self-efficacy expectations to the selection of science-based college majors. Journal of Vocational Behavior,23(3), 329-345. http://dx.doi.org/10.1016/0001-8791(83)90046-5.

Bong, M., \& Skaalvik, E. M. (2003). Academic self-concept and self-efficacy: How different are they really?15, 1-40. https://doi.org/10.1023/A:1021302408382

Bonne, L., \& Johnston, M. (2016). Students' beliefs about themselves as mathematics $\begin{array}{llll}\text { learners. Thinking Skills and } & \text { Creativity, 20, }\end{array}$ https://doi.org/10.1016/j.tsc.2016.02.001

Britner, S. L., \& Pajares, F. (2006). Sources of science self-efficacy of middle school students. Journal of Research in Science Teaching, 43(5), 485-499. https://doi.org/10.1002/tea.20131

Brookby, S. A. (2004). Academic self-efficacy and social self-concept of mathematically gifted high school students in a summer residential program(Publication No. 3133644) [Doctoral dissertation, University of Missouri]. ProQuest Dissertations Publishing.

Butz, A. R., \& Usher, E. L. (2015). Salient sources of early adolescents' self-efficacy in two domains. Contemporary Educational Psychology, 42, 4961.https://doi.org/10.1016/j.cedpsych.2015.04.001

Choy, B. H. (2013). Productive mathematical noticing: What it is and why it matters. Mathematics Education Research Group of Australasia, 186-193. 
Falco, L. D. (2019). An intervention to support mathematics self-efficacy in middle school. Middle School Journal, 50(2), 28-44. https://doi.org/10.1080/00940771.2019.1576580

Fraenkel, J. R., Wallen, N. E., \& Hyun, H. H. (2012). How to design and evaluate research in education. McGraw-Hill.

Gagne, F. (2003). Transforming gifts into talents: The DMGT as a developmental theory. In N. Colangelo \& G. A. Davis (Eds.), Handbook of gifted education (pp. 60-74). Allyn and Bacon.

Gottfried, A. W., Gottfried, A. E., Bathurst, K., \& Guerin, D. W. (1994). Gifted IQ: Early developmental aspects-the Fullerton longitudinal study. Plenum Press.

Grigg, S., Perera, H. N., Mcilveen, P., \&Svetleff, Z. (2018). Relations among math self efficacy, interest, intentions, and achievement: A social cognitive perspective. Contemporary Educational Psychology, 53, 73-86.https://doi.org/10.1016/j.cedpsych.2018.01.007

Hackett, G., \& Betz, N. E. (1981). A self-efficacy approach to the career development of women. Journal of Vocational Behavior, 18, 326-339. https://doi.org/10.1016/00018791(81)90019-1

Hackett, G., \& Betz, N.E. (1989). An exploration of the mathematics self-efficacy mathematics performance correspondence. Journal for Research in Mathematics Education, 20(3), 261-273.

Hair Jr, J. F., Black, W. C., Babin, B. J., \& Anderson, R. E. (1998). Multivariate data analysis. Pearson.

Harrison, C. (2004). Giftedness in early childhood: The search for complexity and connection, Roeper Review, 26(2), 78-84. https://doi.org/10.1080/02783190409554246 http://dx.doi.org/10.30703/cije.653089

Hwang, M. H., Choi, H. C., Lee, A., Culver, J. D., \& Hutchison, B. (2016). The relation between self-efficacy and academic achievement: A 5-year panel analysis. Asia-Pacific Education Researcher, 25(1), 89-98. https://doi.org/10.1007/s40299-015-0236-3

Kesan, C., \& Kaya, D. (2018). Mathematics and science self-efficacy resources as the predictor of academic success. International Online Journal of Educational Sciences, 10 (2), 45-58. http://dx.doi.org/10.15345/iojes.2018.02.004

Kilpatrick, J., Swafford, J., \& Findell, B. (Eds.). (2001). Adding it up: Helping children learn mathematics. National Academies Press.

Klassen, R. M., \& Usher, E. L. (2010). Self-efficacy in educational settings: Recent research and emerging directions. In T. C. Urdan \& S. A. Karabenick (Eds.), Advances in motivation and achievement: Vol. 16A. The decade ahead: Theoretical perspectives on motivation and achievement(pp. 1-33). Emerald Publishing Group.

Kontas, H., \&Ozcan, B. (2017). Adapting sources of middle school mathematics self efficacy scale to Turkish culture. The International Journal of Evaluation and Research in Education, 6(4), 288-294.

Kuo, C. C., Maker, J., Su, F. L., \& Hu, C. (2010). Identifying young gifted children and cultivating problem solving abilities and multiple intelligences. Learning and Individual Differences,20(4), 365-379.https://doi.org/10.1016/j.lindif.2010.05.005

Leech, N. L., Barrett, K. C., \& Morgan, G. A. (2005). SPSS for intermediate statistics: Use and interpretation. Lawrence Erlbaum Associates, Inc.

Lens, W.,\& Rand, P. (2000). Motivation and cognition: their role in the development of giftedness. In Heller, K. A, Monks, F. J, Sternberg, R. J., \& Subotnik, R. F. (Eds.), International handbook of giftedness and talent (pp.193-202). Elsevier Science

Lent, R. W., Lopez, F. G., Brown, S. D., \& Gore, P. A. (1996). Latent structure of the sources of mathematics self-efficacy. Journal of Vocational Behavior, 49, 292-308.

Lin, L., Lee, T., \& Snyder, L. A. (2018). Math self-efficacy and STEM intentions: A person- 
centered approach. Frontiers in Psychology, 9, 2033, 1-13.

https://doi.org/10.3389/fpsyg.2018.02033

Little, D. (1995). Learning as dialogue: The dependence of learner autonomy on teacher autonomy. System, 23(2), 175-181.

Liyd, J. E. V., Walsh, J., \&Yailagh, M. S. (2005). Sex differences in performance attributions, self-efficacy, and achievement in mathematics: If I'm so smart, why don't I know it? Canadian Journal of Education, 28(3), 384-408.

Loo, C.W., \& Choy, J. L. F. (2013). Sources of self-efficacy influencing academic performance of engineering students. American Journal of Educational Research, 1(3), 86-92. https://doi.org/10.12691/education-1-3-4

Madigan, D. J. (2019). A meta-analysis of perfectionism and academic achievement. Educational Psychology Review, 31, 967-989. https://doi.org/10.1007/s10648-01909484-2

Malpass, J. R., O’Neil, H. F., \& Hocevar, D. (1999). Self-regulation, goal orientation, self-efficacy, worry, and high-stakes math achievement for mathematically gifted high school students. Roeper Review, 21(4), 281-288. https://doi.org/10.1080/02783199909553976

Masitoh, L. F., \& Fitriyani, H. (2018). Improving students' mathematics self-efficacy through problem based learning. Malikussaleh Journal of Mathematics Learning (MJML), 1(1), 26-30. https://doi.org/10.29103/mjml.v1i1.679

MONE (2017). Milli Egitim Bakanligi Ortaogretim Kurumlari Yonetmeligi, Ministry of National Education, Ankara. https://ogm.meb.gov.tr/meb_iys_dosyalar/2017_09/20161748_MYLLY_EYYTYM_BAK ANLIYI_ORTAYYRETYM_KURUMLARI_YYNETMELYYY.pdf

Neumeister, K. L. S. (2004). Understanding the relationship between perfectionism and achievement motivation in gifted college students. Gifted Child Quarterly, 48(3), 219231. https://doi.org/10.1177/001698620404800306

O’brien, V., Martinez-Pons, M., \& Kopala, M. (1999). Mathematics self-efficacy ethnic identity, gender, and career interest related to mathematics and science. The Journal of Educational Research, 92(4), 231-235. https://doi.org/10.1080/00220679909597600

Ozcan, B., \&Kontas, H. (2017, 3-5 November). Ortaokul Ogrencilerinin matematik basarisinin yordayicilari: Matematik $\mathrm{Oz}$ yetkinlik kaynaklari aile arkadas ve Ogretmenden algilanan matematik basari beklentisi. Presented at the 1st International Symposium on Social and Educational Sciences Research, Antalya, Turkey.

Ozcan, B., \& Kontas, H. (2020). Investigating relationship between mathematics achievement and sources ofmathematics self-efficacy in high school students. Cumhuriyet International Journal of Education, 9(3), 800-819.

Ozcan, B., \&Kultur, Y. Z. (2019, 25-28 April). Investigation of predictor effect of sources of mathematics self-efficacy on high school last grader students' mathematics achievemet in the university enterence exam, and mathematichs course achivements. Presented at the $28^{\text {th }}$ International Conference on Educational Sciences, Ankara, Turkey.

Pajares, F. (1996). Self-Efficacy beliefs and mathematical problem-solving of gifted students. $\begin{array}{lll}\text { Contemporary Educational 21(4), 325-344. } & \text { Psychology, }\end{array}$ https://doi.org/10.1006/CEPS.1996.0025

Pajares, F., \& Graham, L. (1999). Self-efficacy, motivation constructs, and mathematics performance of entering middle school students. Contemporary Educational Psychology, 24(2), 124-139.

Pajares, F., \& Kranzler, J. (1995). Self-efficacy beliefs and general mental ability in mathematical problem-solving. Contemporary Educational Psychology, 20, 426-443. 
Rimm, S. (2003). Underachievement: A national epidemic. In N. Colangelo \& G. A. Davis (Eds.), Handbook of gifted education (pp. 424-443). Allyn \& Bacon.

Risemberg, R.,\& Zimmerman, B. J. (2010). Self-regulated learning in gifted students. Roeper Review, 15(2), 98-101.https://doi.org/10.1080/02783199209553476

Roberts, S. M., \& Lovett, S. B. (1994). Examining the "F" in gifted: Academically gifted adolescents' physiological and affective responses to scholastic failure. Journal for the Education of the Gifted, 17(3),241-259.https://doi.org/10.1177/016235329401700304

Rodrigez, A. (2003). Comparing math self-efficacy in middle school girls [Unpublished master's thesis]. West Virginia University.

Schober, C., Schutte, K., Koller, O., McElvany, N., \&Gebauer, M. M. (2018). Reciprocal effects between self-efficacy and achievement in mathematics and reading. Learning and Individual Differences, 63, 1-11. https://doi.org/10.1016/j.lindif.2018.01.008

Schweinle, A., \& Mims, G. A. (2009). Mathematics self-efficacy: Stereotype threat versus resilience. Social Psychology of Education, 12(4), 501-514. https://doi.org/10.1007/s11218-009-9094-2

Sternberg, R. J., \& Kaufman, S. B. (2018). Theories and conceptions of giftedness. In S. I. Pfeiffer (Ed.), Theories and conceptions of giftedness (pp. 29-47). Springer.

Stevens, T., Olivarez, A., Lan, W. Y., \& Tallent-Runnels, M. K. (2004). Role of mathematics selfefficacy and motivation in mathematics performance across ethnicity. Journal of Educational Research, 97(4), 208-222. https://doi.org/10.3200/JOER.97.4.208-222

Sukthankar, N. (1999). Cultural factors in mathematics education contributing to the shortage of women professionals in Papua New Guinea. Educational Review, 51(2), 173-181. https://doi.org/10.1080/00131919997605

Talsma, K., Schuz, B., Schwarzer, R., \& Norris, K. (2018). I believe, therefore I achieve (and vice versa): A meta-analytic cross-lagged panel analysis of self-efficacy and academic performance. Learning and Individual Differences, 61, 136-150. https://doi.org/10.1016/j.lindif.2017.11.015

Tannenbaum, A. J. (1997). The meaning and making of giftedness. In N. Colangelo \& G. A. Davis (Eds.), Handbook of gifted education (pp. 27-42). Allyn and Bacon.

Tossavainen, T., Rensaa, R. J., \& Johansson, M. (2019). Swedish first-year engineering students' views of mathematics, self-efficacy and motivation and their effect on task performance. International Journal of Mathematical Education in Science and Technology, 1-16.https://doi.org/10.1080/0020739X.2019.1656827

Tunnicliffe, C. (2010). Teaching able, gifted \& talented children. Sage Publications Ltd.

Usher, E. L., \& Pajares, F. (2006). Sources of academic and self-regulatory efficacy beliefs of entering middle school students. Contemporary Educational Psychology, 31(2), 125-141. https://doi.org/10.1016/j.cedpsych.2005.03.002

Usher, E. L., \& Pajares, F. (2009). Sources of self-efficacy in mathematics: A validation study. Contemporary Educational Psychology, 34(1), 89-101. https://doi.org/10.1016/j.cedpsych.2008.09.002

Usher, E. L., \& Weidner, L. (2018). Sociocultural influences on self-efficacy development. In G. A. D. Liem, \& D. M. Mclnerney (Eds.). Big theories revisited. Information Age Publishing.

Vallerand, R. J., Gagne, F., Senecal, C., \& Pelletier, L. G. (1994). A comparison of the school intrinsic motivation and perceived competence of gifted and regular students. Gifted Child Quarterly, 38(4), 172-175.

Vogel, F. R., \& Human-Vogel, S. (2016). Academic commitment and self-efficacy as predictors of academic achievement in additional materials science. Higher Education Research and Development, 35(6), 1298-1310. https://doi.org/10.1080/07294360.2016.1144574 
Wallace, B. (2000). Teaching the very able child: Developing a policy and adopting strategies for provision. David Fulton Publishers.

Warwick, J. (2008). Mathematical self-efficacy and student engagement in the mathematics classroom. MSOR Connections, 8(3), 31-37. https://doi.org/10.11120/msor.2008.08030031

Watson, K. L. (2015). Examining the effects of college algebra on students' mathematical dispositions [Unpublished master's thesis].Brigham Young University.

Zeldin, A. L., \& Pajares, F. (2000). Against the odds: Self-efficacy beliefs of women in mathematical, scientific, and technological careers. American Educational Research Journal, 37(1), 215-246. https://doi.org/10.3102/00028312037001215

Zeldin, A. L., Britner, S. L., \& Pajares, F. (2008). A comparative study of the self-efficacy beliefs of successful men and women in mathematics, science, and technology careers. Journal of Research in Science Teaching, 45(9), 10361058.http://doi.org/10.1002/tea.20195

Zimmerman, B. J. (2000). Self-efficacy: An essential motive to learn. Contemporary Educational Psychology, 25, 82-91. https://doi.org/10.1006/ceps.1999.1016

Zimmermann, M., Bescherer, C., \& Spannagel, C. (2011). A questionnaire for surveying mathematics self-efficacy expectations of future teachers. Article of German Federal Ministry of Education and Research.

https://www.researchgate.net/publication/236178760_A_questionnaire_for_surveyin gmathematics_self-efficacy_expectations_of_Prospective_teachers

\section{Biographical notes:}

Bahadır Özcan is an Assistant Professor in the Faculty of Education at Adiyaman University, Adıyaman, Turkey. His research interests include educational psychology, self-efficacy, resilience, self-construal, and subjective well-being.

Hakkı Kontaș is an Associate Professor in the Faculty of Education at Adiyaman University, Adiyaman, Turkey. His research interests include curriculum and instruction, self-efficacy, learning strategies and styles, and teacher training.

Ali Ünişen is an Associate Professor in the Faculty of Education at Adiyaman University, Adiyaman, Turkey. His research interests include curriculum and instruction, history of education, teacher training. 